Brief Report

\title{
Control of Soil Extracellular Enzyme Activities by Clay Minerals-Perspectives on Microbial Responses
}

\author{
Folasade K. Olagoke *, Karsten Kalbitz and Cordula Vogel * \\ Chair of Soil Resources and Land Use, Institute of Soil Science and Site Ecology, TU Dresden, Pienner Strasse 19, \\ 01737 Tharandt, Germany; karsten.kalbitz@tu-dresden.de \\ * Correspondence: folasade.olagoke@tu-dresden.de (F.K.O.); cordula.vogel@tu-dresden.de (C.V.)
}

Received: 11 June 2019; Accepted: 23 September 2019; Published: 26 September 2019

\begin{abstract}
Knowledge of how interactions of clay minerals and extracellular enzymes (EEs) influence organic matter turnover in soils are still under discussion. We studied the effect of different montmorillonite contents on EE activities, using two experiments-(1) an adsorption experiment with a commercially available enzyme ( $\alpha$-glucosidase) and (2) an incubation experiment (10 days) where microorganisms were stimulated to produce enzymes through organic carbon $(\mathrm{OC})$ addition (starch and cellulose). Soil mixtures with different montmorillonite contents were created in four levels to a sandy soil: $+0 \%$ (control) $,+0.1 \%,+1 \%$, and $+10 \%$. The potential enzyme activity (pEA) of four enzymes, $\alpha$-glucosidase, $\beta$-glucosidase, cellobiohydrolase, and aminopeptidase, involved in the soil carbon and nitrogen cycle were analysed. The adsorption experiment revealed a reduction in the catalytic activity of $\alpha$-glucosidase by up to $76 \%$ with increasing montmorillonite contents. However, the incubation experiment showed an inhibitory effect on pEA only directly after the stimulation of in-situ EE production by OC addition. At later incubation stages, higher pEA was found in soils with higher montmorillonite contents. This mismatch between both experiments, with a transient reduction in catalytic activity for the incubation experiments, points to the continuous production of enzymes by soil microorganisms. It is conceivable that microbial adaptation is characterized by higher investment in EEs production induced by increasing clay contents and a stabilisation of the EEs by clay minerals. Our results point to the need to better understand EE-clay mineral-OC interactions regarding potential microbial adaptations and EE stabilisation with potentially prolonged activities.
\end{abstract}

Keywords: extracellular enzyme activities; clay minerals; organic carbon; microorganisms; soil organic matter

\section{Introduction}

Knowledge is rapidly expanding on the contribution of microorganisms to soil biogeochemical cycling in relation to the transformation, degradation and stabilisation of soil organic matter (OM) [1-3]. Extracellular enzymes (EEs) arising from microbial activities in soils are well recognized for their role in enabling them to degrade complex organic substrates into low molecular compounds that are readily assimilated by soil flora and fauna [1,4]. Though still under debate [5-8], the catalytic functionality of these EEs is widely accepted to be significant for OM dynamics (storage and turnover) in soils. Any factor or a combination of factors that alter the production and activity of soil enzymes may, therefore, constrain these dynamics.

Many biotic and abiotic factors are known to control the effectiveness and efficiency of EEs and interactions between enzymes and their substrate in soils [9-12]. The soil mineral matrix is one important factor, especially various clay mineral types and concentrations. Available studies have attributed the persistence and stability of many proteins, including EEs, to their association with clay minerals [13-15]. In soils, interactions of clay minerals and EEs often result in adsorption of EEs 
as mediated by their affinity for mineral surfaces [16]. Clay minerals can react as considerable EE inhibitors, due to their binding capacities depending on the specific surface area, surface charge and cation exchange capacity. It was noted that reduced enzyme activities emerge when adsorption onto the clay mineral occurs in a manner that blocks enzyme active sites or in a way that causes enzyme deformation [16]. Nevertheless, enzyme activities could also be enhanced, or at least maintained, if the adsorption on clay minerals stabilizes their structure, which allows enzymes to retain their catalytic activities $[14,17]$. As examples, $\beta$-glucosidase activities were found to be increased by the adsorption to montmorillonite [18], whereas activities of phosphatase and urease were reduced by about $80 \%$ and $29 \%$ compared to their free counterpart $[19,20]$. Furthermore, microorganism's adaptation to their local environment [21,22] could also enhance their activities in terms of EEs production, most importantly the influence of the soil mineral composition. However, studies about the interactions between enzymes and clay minerals mostly cover adsorption experiments with pure clay minerals in buffered solutions $[16,20,23]$. Most investigations are based on commercially available enzymes $[18,19,24]$ and studies that involve natural soils $[25,26]$, where enzymes are produced by the resident microbial community, are less common. Thus, it remains less clear whether existing knowledge about EEs-clay mineral interactions in pure cultures directly mimic what obtains in natural soils with variable clay contents, where enzymes are produced by resident micro-organisms.

The objective of the present work was to study the importance of increasing montmorillonite contents on the potential enzyme activity (pEA) in manipulated soils. We hypothesized a reduced pEA with increasing montmorillonite contents, which was tested by an adsorption experiment. Additionally, we used an incubation experiment to study the effect of increasing montmorillonite contents on pEA of the enzymes produced by the resident microbial community with a focus on their initial response. For both, the adsorption and incubation experiment, a manipulated soil with increasing clay contents were produced from sandy soil by the addition of different amounts of montmorillonite. The resident microbial community was stimulated to produce EEs by the addition of organic substrates differing in decomposability, i.e., starch and cellulose.

\section{Materials and Methods}

\subsection{Soil Materials and Preparation}

The soil used in this study was collected at a research site located at Eberswalde-Müncheberg, Germany $\left(52^{\circ} 30^{\prime} 55.0^{\prime \prime} \mathrm{N} 14^{\circ} 07^{\prime} 40.5^{\prime \prime}\right.$ E). The predominantly sandy soil was collected at $0-10 \mathrm{~cm}$ depth from an erosion hill slope. The soil was classified as a Cutanic Luvisol developed from glacial till. The till was deposited during the Weichselian glaciation. The clay mineral assemblage of soils developed on this material (mainly Luvisols) is very homogenous [27]. The XRD analysis of the $<2 \mu \mathrm{m}$ soil fraction close to our study site (description of this site [28]) revealed illite (31\%), illite-smectite mixed-layer minerals $(61 \%)$, kaolinite $(7 \%)$, and traces of chlorite and quartz (pers. comm. M. Sommer, ZALF, 13 July 2019). Our soil had a $C$ content of $5.9 \mathrm{mg} \mathrm{g}^{-1}$, a cation exchange capacity of $6.3 \mathrm{cmol}_{\mathrm{c}} \mathrm{kg}^{-1}$ (base saturation 21\%), and contained $0.8 \mathrm{mg} \mathrm{g}^{-1}$ and $0.4 \mathrm{mg} \mathrm{g}^{-1}$ oxalate extractable $\mathrm{Fe}$ and $\mathrm{Al}$, respectively, and $2.7 \mathrm{mg} \mathrm{g}^{-1}$ dithionite extractable Fe [29].

The soil was air-dried at $38^{\circ} \mathrm{C}$ and sieved to $<2 \mathrm{~mm}$. Afterwards, the macroaggregates $>250 \mu \mathrm{m}$ were softly broken by applying mortar and pestle and particulate $\mathrm{OM}$ was removed by electrostatic attraction [30] to reduce the amount of labile C. The original soil had a textural composition of $86.4 \%$ sand, $9.2 \%$ silt, and $4.4 \%$ clay. From this, four different treatments with increasing clay content were prepared by adding montmorillonite (2:1 clay mineral) in a logarithmic scale of $+0 \%,+0.1 \%$, $+1 \%$, and $+10 \%$. After the addition of the montmorillonite, the soil was then mixed manually until homogenisation. The soil without montmorillonite addition $(+0 \%)$ was used as control. 


\subsection{Experimental Setup}

We studied the influence of increasing clay contents on the pEA in soils through two complementary experiments using the same soil materials with increasing montmorillonite contents for firstly adsorption and secondly an incubation experiment.

In the first experiment, a conventional adsorption experiment was conducted with a commercially available enzyme, $\alpha$-glucosidase (AG) from Saccharomyces cerevisiae (E.C. 3.2.1.20, Sigma Aldrich, Munich, Germany, 19.3 U/mg of solid, G5003). For this experiment, the OM in the soil materials was destroyed with $10 \%$ hydrogen peroxide $\left(\mathrm{H}_{2} \mathrm{O}_{2}\right)$, before the addition of the montmorillonite, to avoid the reaction of the enzyme with the natural soil OM. This was done to test solely the effect of the increasing montmorillonite content on the pEA. The montmorillonite was added in a logarithmic scale increasing the clay content as mentioned above. With these samples, the enzyme-clay mixture was prepared following the procedure of Gianfreda and Rao [31]. The commercial AG prepared in modified universal buffer (MUB) with $\mathrm{pH} 6$ [32] was added to soil samples in a concentration of $12 \mathrm{U} / \mathrm{mL}$ (that is, $0.62 \mathrm{mg}$ solid/mL according to the supplier). The soil-solution ratio was $0.04: 1(w / v)$ in accordance with Gianfreda and Rao [31]. Specifically, $0.25 \mathrm{~g}$ of soil was weighed into $6.25 \mathrm{~mL}$ MUB containing the AG (enzyme solution). This mixture was then allowed to stand at $4{ }^{\circ} \mathrm{C}$ for $1 \mathrm{~h}$ with shaking at $10 \mathrm{~min}$ interval. Subsequently, the soil with the enzyme solution was then centrifuged with $32 \mathrm{R}$ centrifuge (Universal 32R) at a speed of $1753 \mathrm{~g}$ at $4{ }^{\circ} \mathrm{C}$ temperature for $30 \mathrm{~min}$. The supernatant was discarded and the precipitate was washed with the MUB. For this, the precipitate was resuspended in $6.25 \mathrm{~mL}$ MUB and centrifuged again. This is henceforth referred to as the enzyme clay mixture. The enzyme-clay mixture was then resuspended in MUB in a final volume of $30 \mathrm{~mL}$ to adapt with EA measurement method by Deng, et al. [32]. The pEA of AG was determined in the suspensions of enzyme-clay mixture and in the enzyme solution.

In the second experiment, we incubated the same soils as in the first experiment with increasing montmorillonite contents. Unlike in the first experiment, enzymes were not added to the soil but produced by the resident microbial community. The activity of the resident microbial community was stimulated by the addition of two different sources of organic carbon (OC) differing in decomposability, i.e., starch (S4126, Sigma Aldrich, Germany and cellulose (S3504, Sigma Aldrich). Following a pre-incubation of around 6 month to reduce the amount labile $C$ as much as possible and to allow the resident microbial community to adapt to the different montmorillonite contents, the soil samples were divided into three parts: one part without $\mathrm{OC}$ addition and the other parts were amended with starch or cellulose $\left(1 \mathrm{mg} \mathrm{C} \mathrm{g}^{-1}\right.$ soil) and $10 \mu \mathrm{g}$ ammonium nitrate $\left(\mathrm{NH}_{4} \mathrm{NO}_{3}\right) \mathrm{g}^{-1}$ soil (to prevent nitrogen limitation). The manipulated soils ( $200 \mathrm{~g}$ dry soil) were incubated under controlled conditions $\left(20{ }^{\circ} \mathrm{C}, 50 \%\right.$ of the water holding capacity) for 10 days. Earlier studies have reported that the highest pEA was already reached within 10 days or even started to decrease compared to the first day [33]. For this reason and due to our focus on the initial microbial response to the increased montmorillonite contents regarding pEA after stimulation of the microbial community, we limited the present study to 10 days of soil incubation. The soils with no montmorillonite addition as well as soils with no OC additions were used as controls. Overall, 12 treatments were studied ( 4 soil treatments $(+0 \%,+0.1 \%$, $+1 \%$, and $+10 \%$ montmorillonite addition) $\times 3$ OC treatments (without and 2 with OC (starch or cellulose) addition)). All treatments were destructively sampled for the analyses of 3 EEs important for carbon cycling, the AG, $\beta$-glucosidase (BG) and cellobiohydrolase (CB), and one important enzyme for the cycling of nitrogen, aminopeptidase (AM), at different time steps, 0 (corresponding to $2 \mathrm{~h}$ after the addition of the $\mathrm{OC}), 3$, and 10 days.

\subsection{Enzyme Measurements}

Enzyme analyses were carried out using fluorogenic substrates according to the description of Deng, et al. [32]. Methylumbelliferyl linked (MUF) substrates, $\alpha$-D-glucopyranoside, $\beta$-D-glucopyranoside, $\beta$-D-cellobioside, and L-Leucine-7-amido-4-methylcoumarin hydrochloride (order numbers: 69591, 
M3633, M6018, and L2145, Sigma Aldrich, Munich, Germany) were used for measuring the pEA of AG, BG CB and AM, respectively.

For the adsorption experiment, the pEA of AG was determined in suspension with the enzyme-clay mixture. The soil-solution ratio was adjusted to the protocol of Deng et al. (2011), that is, 1:120 $(w / v)$. Thus, $30 \mathrm{~mL}$ of buffer was added to the precipitates (enzyme-clay mixture) and homogenised before pipetting into the microplate. Microplates were measured fluorometrically (excitation $360 \mathrm{~nm}$, emission $450 \mathrm{~nm}$ ) for $60 \mathrm{~min}$ at 1-min intervals [34] using a microplate reader (Multi-Mode Microplate Reader SynergyTM HTX, Bio-Tek Instruments, Inc., USA). The kinetic parameters, $K_{m}$ and $V_{\max }$, of AG affected by adsorption were studied using nine different substrate concentrations, between 50 and $8000 \mu \mathrm{M}$ and calculated according to the Michaelis Menten's equation (Equation (1)). Where $v$ is the initial velocity (rate of reaction) at substrate concentration (S), $V_{\max }$ is the maximum velocity and $K_{m}$ (Michaelis constant) is the substrate concentration at half of $V_{\max }$ [35]. The kinetic parameters of AG were determined for the precipitate and the pure enzymes by fitting pEA data by Michaelis Menten's equation [34,36]. For the AG activities, the pEA for $8000 \mu \mathrm{M}$ substrate concentration was presented.

$$
v=\frac{V_{\max }[S]}{K_{m}+[S]}
$$

For the incubated soil (incubation experiment), the pEA of the four EEs, AG, BG (EC 3.2.1.21), CB (EC 3.2.1.91) and AM, which were naturally produced by the soil residence organisms were measured in the soil suspensions by mixing $1 \mathrm{~g}$ soil material with $120 \mathrm{~mL}$ sterile DI water and homogenised using a magnetic stirrer at the speed of $400 \mathrm{rpm}$ instead of $600 \mathrm{rpm}$ as stated in Deng et al. (2011). For each of the EEs, $400 \mu \mathrm{M}$ substrate concentration was used. Each enzyme analysis included standard, sample, sample control and substrate control (negative control/autohydrolysis) assay wells within a microplate [32,37]. The fluorescence of the solution was determined at $360 \mathrm{~nm}$ excitation and $450 \mathrm{~nm}$ emission filters using a microplate reader.

For each treatment, enzyme analyses were carried out in three independent replicates. The pEA from both experiments was calculated based on standard curves of MUF according to German, et al. [37]. In order to adapt to the calculation of German, et al. [37], quench assay was included following the same procedure as the standard wells with water used instead of soil suspension [32,37]. The pEA data of commercially available AG added to soil are represented as $\mu \mathrm{mol} \mathrm{h} \mathrm{h}^{-1} \mathrm{~g}^{-1}$ of soil dry weight and that of EEs measured in the natural soils as $n m o l h^{-1} \mathrm{~g}^{-1}$ of soil dry weight.

\subsection{Statistical Analysis}

We considered generalized linear model (GLM) to evaluate the variation in the pEA due to increase in the montmorillonite (MT) contents, OC addition and their interaction (MT:OC) in the soil samples. Separation and comparison of means for these variables, following a significant GLM model, were achieved with Tukey HSD-Test at $p<0.05$. Considering montmorillonite contents and added OC as main explanatory factors and pEA as the response variable, we fitted separate models for each sampling day and EEs, with choice of error distribution depending on the normality of each subset of pEA dataset. For those that are normally distributed we choose Gaussian, and in case of a deviation from normality, Gamma was considered. To separate the effects of montmorillonite and OC, both were introduced as main factor into the same model with their interaction. For model results, assessment of significance and the corresponding $p$-value were realized by using likelihood ratio test of the full model against the NULL (a model with intercept only, where no explanatory variable was included) and other alternative models. In all cases, differences of $p<0.05$ were regarded as statistically significant. The percentage of variability explained by individual factor (that is, MT, OC, MT:OC) in each model was calculated as a ratio of the variability due to this factor and the total variability among samples [38]. For all data presentation, we chose mean values and the corresponding standard error (S.E.) of the selected variables. All statistical data analyses were performed using R software for statistical computing version 3.4.4 [39]. 


\section{Results}

\subsection{The $p E A$ of AG Added to the Soil (Adsorption Experiment)}

The increasing montmorillonite contents significantly reduced the pEA of the commercial AG, apart from the treatment $+0.1 \%$ (Figure 1$)$. The lowest pEA $\left(3.85 \mu \mathrm{mol} \mathrm{h} \mathrm{h}^{-1} \mathrm{~g}^{-1}\right)$ was recorded in the soil where montmorillonite contents were increased by $+10 \%$. In comparison to the soil with no montmorillonite addition, about $40 \%$ and $76 \%$ reduction in pEA (Figure 1, inset) were due to the addition of $1 \%$ and $10 \%$ montmorillonite, respectively.

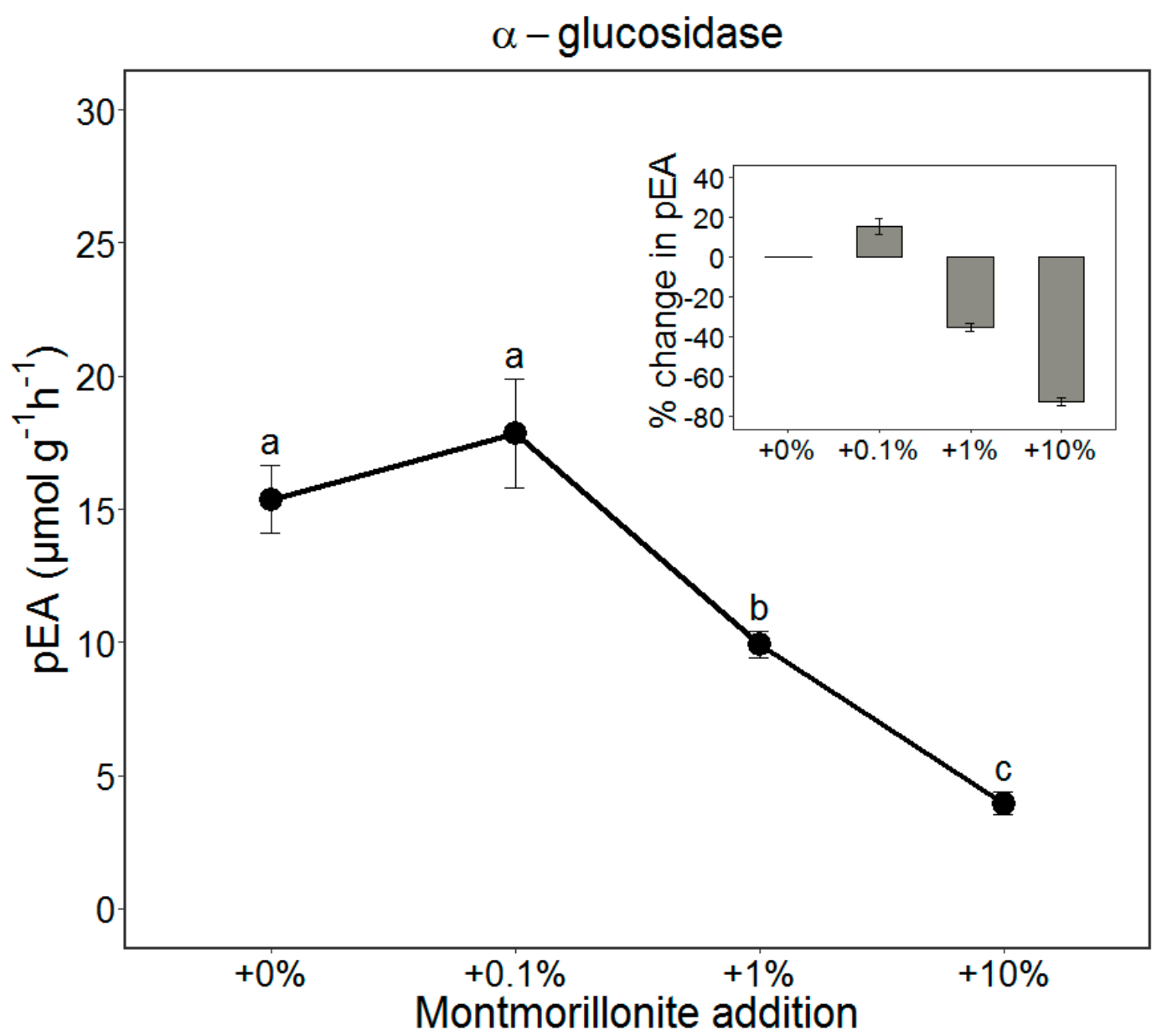

Figure 1. Increasing montmorillonite addition and the effect on potential enzyme activity of pure $\alpha$-glucosidase. The inset figure presents the change in the $\mathrm{pEA}$ relative to the soil with no montmorillonite addition. Bars are standard error of means $(n=3)$.

The $V_{\max }$ of the pure AG (i.e., not added to the soil) was one order of magnitude higher than the values obtained when added to soils (Table 1 ). The montmorillonite addition significantly reduced the $V_{\max }$ and resulted in the lowest values for the $10 \%$ treatment. The $K_{m}$ of the soil with $10 \%$ montmorillonite addition was higher than the pure enzyme and all other treatments, however with no significant difference (Table 1). 
Table 1. The effect of montmorillonite addition to soil on the kinetic parameters $\left(V_{\max }\right.$ and $\left.K_{m}\right)$ of $\alpha$-glucosidase (AG) obtained in the enzyme-clay mixture. $V_{\text {max }}$ is expressed in $\mu \mathrm{mol} \mathrm{g}^{-1} \mathrm{~h}^{-1}\left(^{*} \mu \mathrm{molh}^{-1}\right)$. $K_{m}$ values are provided in $\mu \mathrm{M}$.

\begin{tabular}{ccc}
\hline & ${ }^{\mathbf{1}} \boldsymbol{V}_{\max }$ & ${ }^{\mathbf{1}} \boldsymbol{K}_{m}$ \\
\hline * Pure enzyme & $238.1 \pm 0.8^{\mathrm{a}}$ & $2512.8 \pm 326.7^{\mathrm{a}}$ \\
$+0 \%$ & $20.3 \pm 2.4^{\mathrm{b}}$ & $1877.1 \pm 114.1^{\mathrm{a}}$ \\
$+0.1 \%$ & $24.3 \pm 2.4^{\mathrm{b}}$ & $1981.3 \pm 118.9^{\mathrm{a}}$ \\
$+1 \%$ & $12.9 \pm 1.1^{\mathrm{c}}$ & $1791.3 \pm 18.9^{\mathrm{a}}$ \\
$+10 \%$ & $5.7 \pm 1.1^{\mathrm{e}}$ & $3086.3 \pm 690.5^{\mathrm{a}}$ \\
\hline
\end{tabular}

${ }^{1}$ Mean \pm standard error $(\mathrm{n}=3),{ }^{*} \mathrm{n}=2$, Values with the same superscript in column are not significantly different $(\mathrm{p}<0.05)$.

\subsection{Changes in the $p E A$ of EEs during the Incubation Period (Incubation Experiment)}

Both factors, the montmorillonite and OC type, as well as their interactions (MT:OC), had significant effects on the pEA for all EEs at day 0 (Table 2). The relative importance of the clay content versus OC type and/or MT:OC on $\mathrm{pEA}$ varied over the course of the experiment, whereas the interactions between the clay content and the added OC explained up to 40 to $50 \%$ of pEA variation at day 10 (Table 2).

\subsubsection{Stimulation of the Microorganisms by OC Addition}

The addition of the OC substrates (starch and cellulose) to the soil treatments successfully stimulated the production of EEs by the resident soil microorganisms with a significant increase in pEA activities compared to the control for all EEs measured at day 0 (Figure 2). Over the incubation time, a decrease in pEA was recorded compared to day 0 in soils where specific EE production was stimulated by the OC addition (Figures 2-4). The OC addition explained between $37 \%$ and $83 \%$ of the variation in the pEA values at day 0 and 3 (Table 2). Apart from the AM, where both cellulose and starch addition caused an increase in pEA, the results showed an enzyme type-dependent increase after OC addition. Thus, the highest $\mathrm{pEA}$ was recorded for the AG in the soil with starch addition and for $C B$ in the soil with added cellulose. The BG showed the highest pEA in the soils with cellulose (Figure 2), whereas an increase in pEA was also found in the soil with starch addition. 
Table 2. Summary of the GLM results for the differences in potential enzyme activities (pEA) due to added montmorillonite (MT), OC (starch or cellulose), and their interactions (MT:OC) over the period of the incubation experiment. Significance was assessed using likelihood ratio tests. Numbers in bracket indicate the percentage of variation explained by the respective variables.

\begin{tabular}{|c|c|c|c|c|c|c|c|c|c|c|c|c|c|}
\hline & \multicolumn{5}{|c|}{ DAY 0} & \multicolumn{4}{|c|}{ DAY 3} & \multicolumn{4}{|c|}{ DAY 10} \\
\hline & Df & \multicolumn{2}{|c|}{ Deviance } & $\begin{array}{l}\text { Residual. } \\
\text { Deviance }\end{array}$ & $p$-Value & \multicolumn{2}{|c|}{ Deviance } & \multirow[t]{2}{*}{$\begin{array}{l}\text { Residual. } \\
\text { Deviance }\end{array}$} & \multirow[t]{2}{*}{$p$-Value } & \multicolumn{2}{|c|}{ Deviance } & \multirow[t]{2}{*}{$\begin{array}{l}\text { Residual. } \\
\text { Deviance }\end{array}$} & \multirow[t]{2}{*}{$p$-Value } \\
\hline & & & & & & & & & & & & & \\
\hline NULL & & & & 44.22 & & & & 4.98 & & & & 2532.60 & \\
\hline MT & 3 & 11.58 & (26) & 32.64 & $<0.001$ & 0.77 & (15) & 4.21 & $<0.001$ & 449.83 & (18) & 2082.78 & $<0.001$ \\
\hline OC & 2 & 23.75 & (54) & 8.89 & $<0.001$ & 1.88 & (38) & 2.33 & $<0.001$ & 366.82 & (15) & 1715.96 & $<0.001$ \\
\hline MT:OC & 6 & 6.28 & (14) & 2.61 & $<0.001$ & 1.84 & (37) & 0.49 & $<0.001$ & 1168.10 & (46) & 547.85 & $<0.001$ \\
\hline \multicolumn{14}{|l|}{ BG } \\
\hline NULL & & & & 17.02 & & & & $10,0343.00$ & & & & 3.68 & \\
\hline MT & 3 & 2.01 & (12) & 15.01 & $<0.001$ & $11,353.00$ & (11) & $88,991.00$ & 0.01 & 1.65 & $(45)$ & 2.03 & $<0.001$ \\
\hline OC & 2 & 6.69 & (39) & 8.32 & $<0.001$ & $41,167.00$ & (41) & $47,824.00$ & $<0.001$ & 0.56 & (15) & 1.47 & $<0.001$ \\
\hline MT:OC & 6 & 7.18 & $(42)$ & 1.14 & $<0.001$ & $30,748.00$ & (31) & $17,076.00$ & $<0.001$ & 1.09 & (30) & 0.38 & $<0.001$ \\
\hline \multicolumn{14}{|l|}{$\mathrm{CB}$} \\
\hline NULL & & & & 29.47 & & & & 5211.60 & & & & 7393.80 & \\
\hline MT & 3 & 4.94 & (17) & 24.53 & $<0.001$ & 2150.65 & $(41)$ & 3061.00 & $<0.001$ & 256.96 & $(4)$ & 7136.80 & 1.00 \\
\hline OC & 2 & 18.40 & (62) & 6.14 & $<0.001$ & 2003.57 & (38) & 1057.40 & $<0.001$ & 1518.03 & (21) & 5618.80 & $<0.001$ \\
\hline MT:OC & 6 & 5.32 & (18) & 0.82 & $<0.001$ & 351.02 & $(7)$ & 706.40 & 0.1 & 3153.37 & (43) & 2465.40 & $<0.001$ \\
\hline \multicolumn{14}{|l|}{$\mathrm{AM}$} \\
\hline NULL & & & & $38,262.00$ & & & & 11.76 & & & & 20.59 & \\
\hline MT & 3 & 1922.70 & (5) & $36,339.00$ & $<0.001$ & 0.43 & $(4)$ & 11.36 & 0.01 & 1.29 & $(6)$ & 19.30 & $<0.001$ \\
\hline OC & 2 & $24,226.30$ & (63) & $12,113.00$ & $<0.001$ & 9.84 & (84) & 1.52 & $<0.001$ & 11.27 & (55) & 8.02 & $<0.001$ \\
\hline MT:OC & 6 & 7679.00 & (20) & 4434.00 & 0.05 & 0.90 & $(8)$ & 0.62 & $<0.001$ & 6.82 & (33) & 1.20 & $<0.001$ \\
\hline
\end{tabular}


DAY 0
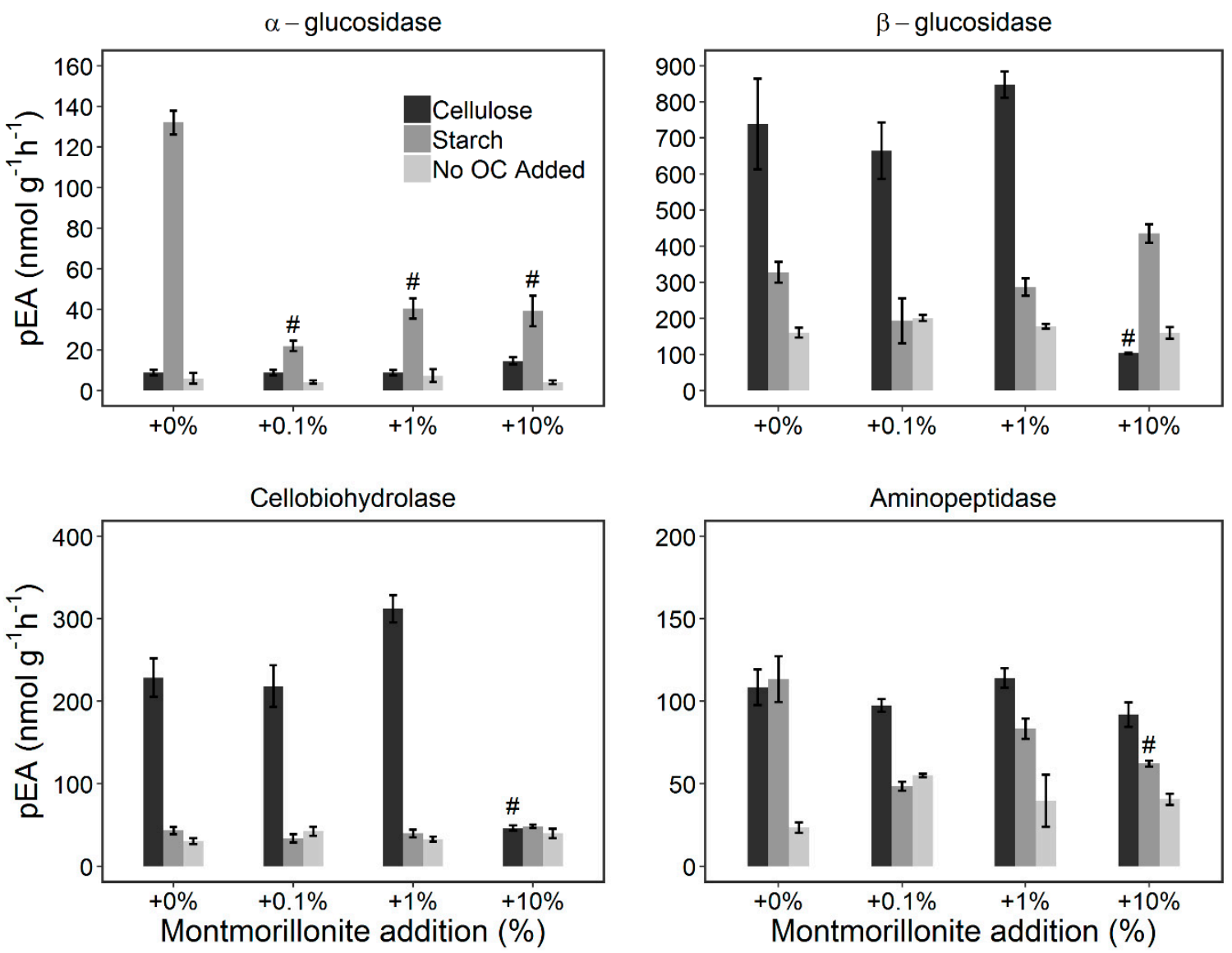

Figure 2. The potential enzyme activities (pEA) of $\alpha$-glucosidase (AG), $\beta$-glucosidase (BG), cellobiohydrolase (CB), and aminopeptidase (AM) measured in the soil manipulated by increasing montmorillonite addition without added OC or with the addition of OC (starch or cellulose) at day 0 of the incubation. Error bars represent standard error of means $(n=3)$. Bars with statistically significant difference $(p<0.05)$ from the control $(+0 \%)$ are marked with \# (decrease in $\mathrm{pEA})$. Mean comparison was done among treatments in the same group (cellulose or starch). 


\section{DAY 3}
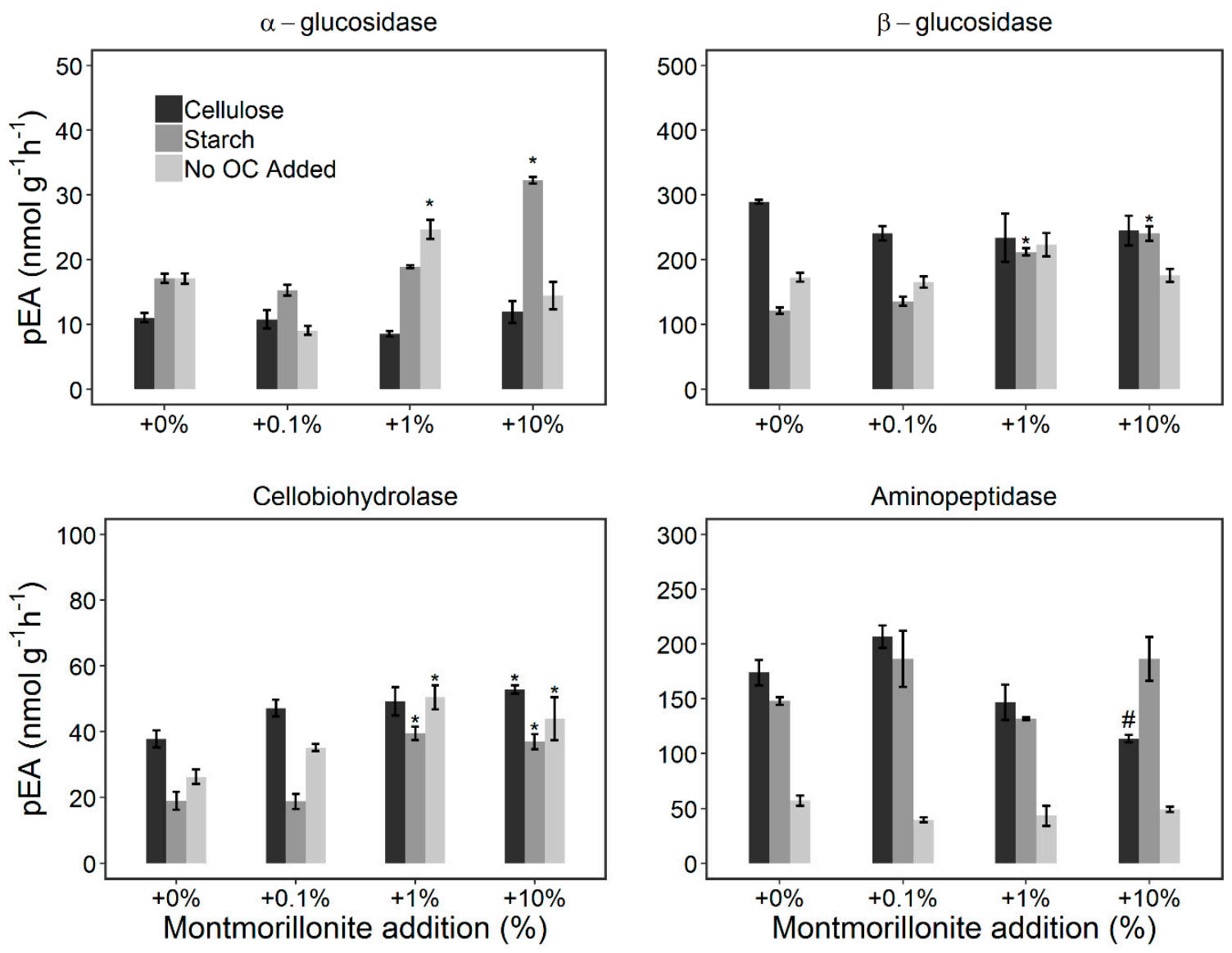

Figure 3. The potential enzyme activities (pEA) of $\alpha$-glucosidase (AG), $\beta$-glucosidase (BG), cellobiohydrolase (CB), and aminopeptidase (AM) measured in the soil manipulated by increasing montmorillonite addition without added OC or with the addition of OC (starch or cellulose) at day 3 of the incubation. Error bars represent standard error of means $(n=3)$. Bars with statistical significant difference $(p<0.05)$ from the control $(+0 \%)$ are marked with * (increase in pEA) and \# (decrease in pEA). Mean comparison was done among treatments in the same group (cellulose or starch). 


\section{DAY 10}

$\alpha$-glucosidase

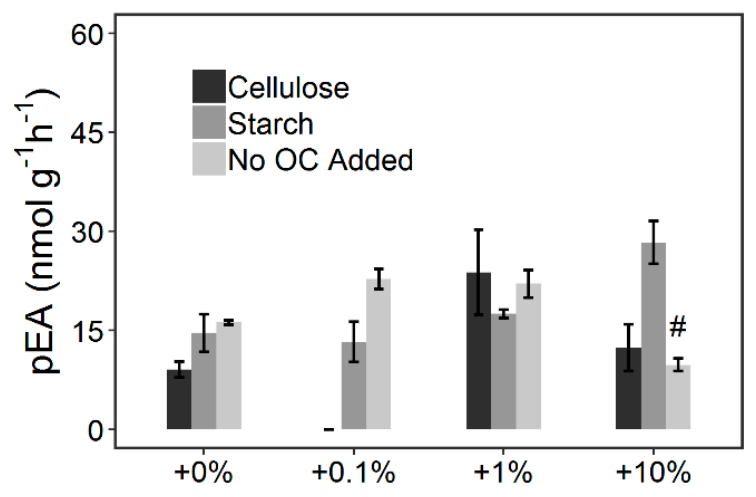

Cellobiohydrolase

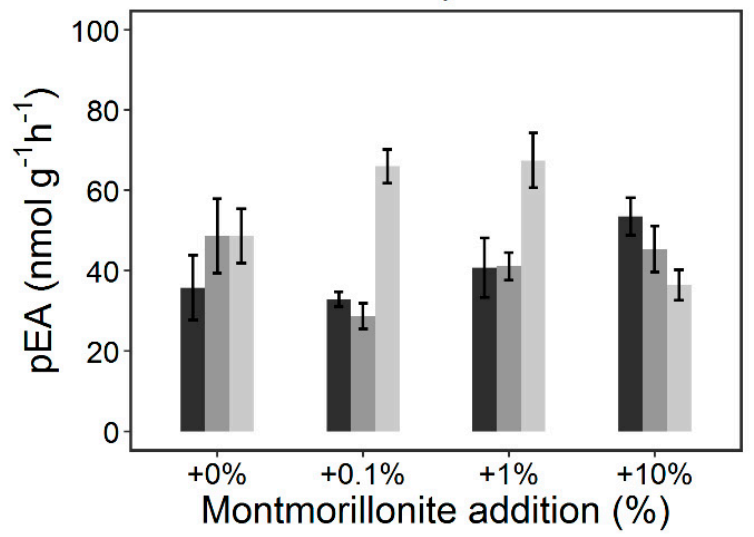

$\beta$-glucosidase

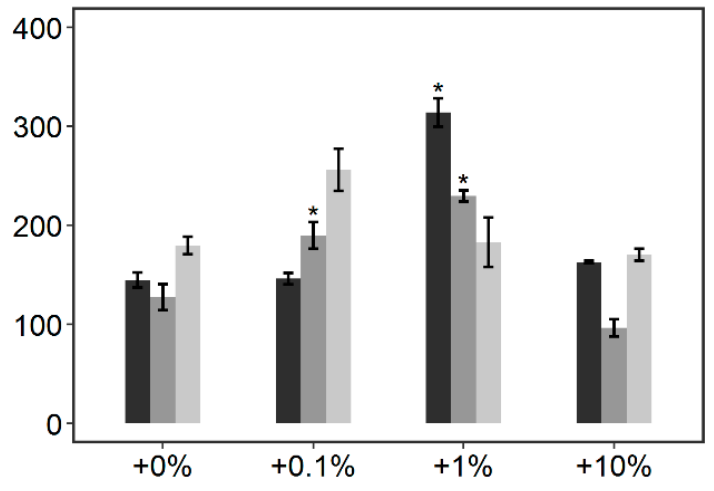

Aminopeptidase

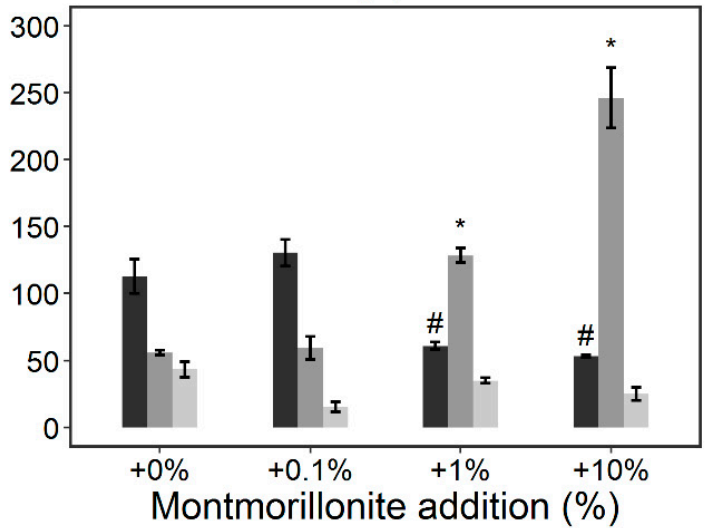

Figure 4. The potential enzyme activities (pEA) of $\alpha$-glucosidase (AG), $\beta$-glucosidase (BG) cellobiohydrolase (CB) and aminopeptidase (AM) measured in the soil manipulated by increasing montmorillonite addition without added OC or with the addition of OC (starch or cellulose) at day 10 of the incubation. Error bars represent standard error of means $(n=3)$. Bars with statistical significant difference $(p<0.05)$ from the control $(+0 \%)$ are marked with * (increase in pEA) and \# (decrease in pEA). Mean comparison was done among treatments in the same group (cellulose or starch).

\subsubsection{Effect of Montmorillonite Addition}

The various montmorillonite contents explained 5 to $45 \%$ of the pEA variation for the incubation experiment (Table 2). In soils without OC addition, no significant reduction in pEA with increasing montmorillonite contents were found (Figure 2). Furthermore, no considerable effect of increasing clay contents on pEA was observed in the soils where EEs were not involved in OC degradation e.g., AG in degradation of cellulose (see Figures $2-4$ ). In soils with $+10 \%$ montmorillonite content and OC addition we observed significantly reduced pEA of AG in the soil with starch addition, and for BG and CB, in the soil with cellulose addition by about $70 \%, 86 \%$, and $80 \%$ (Figure 2), respectively, at the beginning of the incubation. This reduction was in the same order of magnitude as found for AG in the adsorption experiment. However, over the incubation time a mismatch to this $\mathrm{pEA}$ inhibition by increased montmorillonite contents became obvious. After three days, the enzymes involved in C cycling (AG, BG, CB) showed higher pEA values in the soils with $+10 \%$ montmorillonite content compared to the control with $+0 \%$ montmorillonite addition (Figure 3 ). The soil with $+10 \%$ montmorillonite addition showed the highest $\mathrm{pEA}$ after three days for AG and the highest $\mathrm{pEA}$ values for AM after 10 days (Figures 2-4). 


\section{Discussion}

\subsection{The Inhibitory Effect of Clay Minerals on the Potential Enzyme Activity}

We found the expected reduction in pEA with increasing clay contents due to the addition of the clay mineral montmorillonite. Soil samples with a $10 \%$ montmorillonite addition yielded the highest reduction (ca. 76\%) in the activities of the commercial AG (Figure 1). This result aligns with reports of earlier studies [18-20,40], where 29 to $83 \%$ reduction in pEAs were found for phosphatase, urease and proteases added to pure clay minerals in suspension, even though other enzymes were studied. This observed reduction in pEA was most likely due to higher EEs' adsorption with increasing clay contents. The inhibitory effect of clay minerals on pEA has been attributed to the adsorption capacity of clay minerals [41,42]. In this study, we used montmorillonite, an expandable 2:1 clay mineral, which has a high affinity to adsorb EEs, when compared to other types of clay minerals [25]. As the effect on the EEs can be dependent on clay mineral type [20,43], it could be interesting to clarify the consistency of the pattern recorded in further studies involving other types of clay minerals.

Moreover, clay minerals can affect the pEA by conformational changes of the EEs [25,44]. The binding between enzymes and clay minerals can disrupt the active site of the enzyme, preventing the binding of a substrate [45]. Depending on enzyme-clay mineral binding, clay minerals can be competitive, uncompetitive or noncompetitive inhibitors with different effect on the kinetic parameters ( $K_{m}$ and $V_{\max }$ ) of the enzyme [46]. We found decreasing $V_{\max }$ values compared to the pure enzyme and with increasing clay contents with no significant differences among $K_{m}$ values for the adsorption experiment (Table 1). Competitive inhibitors bind at the active site of the enzyme preventing the enzyme from substrate binding resulting in a raised $K_{m}$, while the $V_{\max }$ remains unchanged. An uncompetitive counterpart binds to the enzyme when substrate is bound to the enzyme and lowers both the $V_{\max }$ and $K_{m}$. While the non-competitive binds to the enzyme at a separate binding site, either in a free state or in association with the substrate and lowers the $V_{\max }$ while the $K_{m}$ remains unchanged. Thus, based on our results montmorillonite can be considered as non-competitive inhibitor. In addition to the remaining pEA (Figure 1), this underpins the hypothesis that the adsorbed AG still has the ability for OC degradation while bound to clay. However, less active clay minerals as kaolinite might act differently.

In the incubation experiment, the result obtained at day 0 in the soils amended with OC, generally matched with the expected trend of a reduced pEA upon adsorption on clay minerals for AG, BG, and CB. However, this initial inhibitory effect of clay minerals on pEA was not asserted for the later days. Consequently, this transient reduction in catalytic activity of the enzymes next to behaviour as non-competitive inhibitor points to a persistence of EE activity and/or a potential microbial adaptation due to enzyme-clay mineral binding.

\subsection{Persistence of the EEs Due to Protection by the Clay Minerals}

As the pEA reduced drastically with increasing montmorillonite contents compared to the control directly after OC addition, perhaps freshly produced EEs are more susceptible to adsorption on mineral surfaces. In this case, the freshly produced EEs adsorb onto clay minerals upon production by the microorganism, which then resulted in a pronounced pEA reduction (Figure 2). Nonetheless, we found a higher pEA for the EEs (e.g., for BG) produced by the resident microbial community in soils with higher montmorillonite contents $(+1$ and $+10 \%)$ during the incubation experiment at day 3. This could be an indication that the EEs adsorbed by the clay minerals might be stabilized by adsorption. As a cumulative effect of continuous production and adsorption, higher pEA occurred in the subsequent days as found in the case of AG in the soil with starch addition and BG in the soil with cellulose addition. Clay minerals have been suggested as potential support for prolonged catalytic activities of EEs in enzyme hybrid biocatalyst [17]. Furthermore, Tietjen and Wetzel [18] showed an increase in pEA of BG in solution with clay minerals (montmorillonite and Lake basin clay) and a decrease when the clay minerals were removed. Also within natural soils, the clay-sized fraction was 
found to be associated with high enzyme activities [34], pointing to stabilisation of EEs with prolonged activities. In this case, it needs to be kept in mind that we report pEA activities measured in soil suspension, which implies that the resulting pEA originated from both the adsorbed and free EEs. However in soils, EEs are most likely rarely free in solution [7]. Thus, the pEA usually measured in soils is indicative of an overall enzyme concentration [10]. This points to a cumulative effect resulting from a continuous or even an increased enzyme production, especially when ca. 70 to $80 \%$ of the EE activity could be switched off by adsorption to clay minerals. Nevertheless, further research is required to gain more insight into the question, if increased clay mineral contents foster an increased EE production and/or are responsible for retaining the catalytic properties of the EEs after adsorption and if so, for how long. A combination of protein extraction and determinations coupled with metagenomics and visualization techniques using sterilized soil with known microorganism and a variety of natural soils might be useful to gather more information about this question.

\subsection{Potential Microbial Adaptation to Reduced Potential Enzyme Activities}

Even though we learned from the adsorption experiment, that increasing montmorillonite contents reduced the pEA, soils without OC addition (starch, cellulose) and increasing montmorillonite at later incubation times did not show a corresponding reduction (Figure 2). Moreover, increasing montmorillonite contents resulted in increasing $\mathrm{pEA}$ at certain points during the incubation experiment. Wei, et al. [47] also found higher pEA in artificial soils with increased clay minerals contents. According to Wardle [48], soils with high clay contents tend to promote biomass build-up upon substrate addition, when compared with corresponding, coarser-textured soils'. Thus, the higher enzyme activities could result from increased microbial biomass, as found by Wei et al. [47]. However, it was also indicated that montmorillonite stimulates microbial biomass and activity mainly due to its buffering capacity $[49,50]$ and related increases in $\mathrm{pH}$ values, which has been the case for Wei et al. [47]. Although a direct relationship between increasing enzyme activities and microbial biomass cannot be excluded, an increase in microbial biomass is unexpected as we kept the $\mathrm{pH}$ the same for all treatments.

An alternative explanation, not mutually exclusive, might be that microorganisms adapt to decreased $p E A$ with a partial compensation of the pEA reduction. Such a microbial adaption to increasing clay mineral content and decreasing pEA could explain the mismatch between the results of our adsorption and an incubation experiment. Similar observations were done by Adamczyk et al. [12], although the authors studied the inhibitory effect of tannin. The authors also suggested a response of the soil microbial population, which potentially secreted more de novo synthesized enzymes over time. Our result might equally imply an adaptation of soil microbial community, for example, through further EEs production when the initially produced enzymes and/or cleaved substrate are adsorbed by clay minerals. Maybe an increased production of EEs by microorganisms becomes a strategy to compensate for the adsorption effect of clay mineral and/or to maximize a substrate return on the energy investment towards the production of enzymes within the soil matrix. Allison, et al. [51] claimed that soil physical properties, nutrient availability, and competitive interaction alter enzyme production, given the cost-to-benefit ratio. It is supposed, even if it sounds paradox from an energetic point of view, that nutrient limitation could stimulate an increased EEs production [52,53]. This has also been found for pure cultures [54]. Thus, it seems to be reasonable to assume that other factors such as soil physical constraints (accessibility) might influence the EEs production. In particular, clay minerals that adsorb EEs, and alter their activities and accessibilities, might in turn control EEs production.

In addition to that, the same functional-enzyme type can be produced by different microorganisms or strains of a particular microorganism [55]. Thus, the same EEs from different sources could differ in their response to the environmental conditions or in their affinity for surfaces [24,56]. For instance, Kedi, et al. [56] studied the adsorption of three phosphatases produced from two strains Hebeloma cylindrosporum and one Suillus collinitus in tropical soils. Their results showed diversities in the adsorption of the two fungi phosphatases on soils with a considerable divergence between the enzymes. The authors described Suillus phosphatase as more $\mathrm{pH}$-dependent in its affinity to soil and loss of 
activity upon adsorption than Hebeloma phosphatase. This suggests a divergence in the response of the same functional-enzyme type to presumably similar environmental conditions. Thus, such microbial adaptation to increasing clay mineral contents by a functional shift towards microbial strains with advantages for more viable enzyme production under the condition of high clay contents could also be conceivable as explanation for our results.

Furthermore, the production of extracellular polymeric substances was suggested to prolong the activity of enzymes [57]. The production of such compounds could, therefore, be assumed to serve as another valid adaptation strategy to increasing clay contents with high adsorption potential, which could explain our findings.

If these microbial adaptations to higher clay contents hold true in the way that microorganisms either produce more EE or save their enzymes by the production of other microbial organic compounds, these microbial-derived constituents would most likely contribute to soil OM storage [58]. Thus, microbial adaption might be an important process responsible for the often observed increasing $\mathrm{C}$ storage with increasing clay content.

\section{Conclusions}

Our study implies three key findings, firstly, montmorillonite contents caused an inhibitory effect on pEA. Secondly, the inhibitory effect was only discernible when microorganisms were stimulated by the OC addition, thus corresponded with stimulated EEs production by the resident microorganisms. Thirdly, the reduction in pEA due to increased montmorillonite contents was partly overcome during the incubation. Accordingly, clay minerals could support EEs by stabilisation, as a higher pEA was found in soil with higher montmorillonite contents at later days. The observed pEA sustainment at later stages of the incubation might indicate a cumulative effect of sustaining the functionality of the enzyme upon adsorption and/or a microbial adaptation e.g., a stimulated microbial enzyme production. Our results point to the need for gaining an advanced understanding of enzyme-clay mineral relationships and the subsequent microbial responses beyond the consecutive adsorption effect of clay minerals. Until now, the extent of EEs activities in adsorbed states are still not fully resolved, even when it is important to gain a better understanding of the extracellular components of soil OM decomposition. Meanwhile, strong uncertainties exist about the balance between substrate and microorganism encounter rate within the soil structure. It is not known how this is influencing the microbial energy costs to carry out and maintain their enzymatic apparatus. In further studies, the microbial response to the EEs-clay association and their implications for OM turnover and storage should get more attention. We would like to encourage more studies that take into account the clay mineral influence on the source of production (microorganisms) as well as the stabilisation effect of clay minerals on the EEs activities. These relationships might be important for OM storage and dynamics in soils and could be one step to providing more information about microbial processes controlling carbon stabilisation in soils.

Author Contributions: F.K.O. set up and performed the experiments, collected and analysed data and wrote the manuscript; C.V. contributed to the experiment set up and by commenting on and editing the paper; K.K. contributed by evaluating the data and by commenting on and editing the paper.

Funding: This work was supported by the Deutsche Forschungsgemeinschaft DFG (VO 2111/1-1) and a scholarship funded by the Graduate Academy of the Technische Universität Dresden (Germany) for Folasade Kemi Olagoke.

Acknowledgments: We would like to thank Michael Sommer (ZALF Müncheberg, Germany) who provided information on the clay mineral composition using XRD.

Conflicts of Interest: The authors declare that they have no conflicts of interest. 


\section{References}

1. Burns, R.G.; DeForest, J.L.; Marxsen, J.; Sinsabaugh, R.L.; Stromberger, M.E.; Wallenstein, M.D.; Weintraub, M.N.; Zoppini, A. Soil enzymes in a changing environment: Current knowledge and future directions. Soil Biol. Biochem. 2013, 58, 216-234. [CrossRef]

2. Pronk, G.J.; Heister, K.; Vogel, C.; Babin, D.; Bachmann, J.; Ding, G.-C.; Ditterich, F.; Gerzabek, M.H.; Giebler, J.; Hemkemeyer, M.; et al. Interaction of minerals, organic matter, and microorganisms during biogeochemical interface formation as shown by a series of artificial soil experiments. Biol. Fertil. Soils 2017, 53, 9-22. [CrossRef]

3. Nunan, N.; Leloup, J.; Ruamps, L.S.; Pouteau, V.; Chenu, C. Effects of habitat constraints on soil microbial community function. Sci. Rep. 2017, 7, 4280. [CrossRef] [PubMed]

4. Allison, S.D. Cheaters, diffusion and nutrients constrain decomposition by microbial enzymes in spatially structured environments. Ecol. Lett. 2005, 8, 626-635. [CrossRef]

5. Brookes, P.C.; Chen, Y.; Chen, L.; Qiu, G.; Luo, Y.; Xu, J. Is the rate of mineralization of soil organic carbon under microbiological control? Soil Biol. Biochem. 2017, 112, 127-139. [CrossRef]

6. Kaiser, C.; Franklin, O.; Richter, A.; Dieckmann, U. Social dynamics within decomposer communities lead to nitrogen retention and organic matter build-up in soils. Nat. Commun. 2015, 6, 8960. [CrossRef] [PubMed]

7. Schimel, J.; Becerra, C.A.; Blankinship, J. Estimating decay dynamics for enzyme activities in soils from different ecosystems. Soil Biol. Biochem. 2017, 114, 5-11. [CrossRef]

8. Kuzyakov, Y.; Blagodatskaya, E.; Blagodatsky, S. Comments on the paper by Kemmitt et al. (2008) 'Mineralization of native soil organic matter is not regulated by the size, activity or composition of the soil microbial biomass-A new perspective' [Soil Biology \& Biochemistry 40, 61-73]: The biology of the Regulatory Gate. Soil Biol. Biochem. 2009, 41, 435-439. [CrossRef]

9. Turner, S.; Schippers, A.; Meyer-Stüve, S.; Guggenberger, G.; Gentsch, N.; Dohrmann, R.; Condron, L.M.; Eger, A.; Almond, P.C.; Peltzer, D.A.; et al. Mineralogical impact on long-term patterns of soil nitrogen and phosphorus enzyme activities. Soil Biol. Biochem. 2014, 68, 31-43. [CrossRef]

10. Wallenstein, M.D.; Weintraub, M.N. Emerging tools for measuring and modeling the in situ activity of soil extracellular enzymes. Soil Biol. Biochem. 2008, 40, 2098-2106. [CrossRef]

11. Or, D.; Smets, B.F.; Wraith, J.M.; Dechesne, A.; Friedman, S.P. Physical constraints affecting bacterial habitats and activity in unsaturated porous media-A review. Adv. Water Resour. 2007, 30, 1505-1527. [CrossRef]

12. Adamczyk, B.; Karonen, M.; Adamczyk, S.; Engström, M.T.; Laakso, T.; Saranpää, P.; Kitunen, V.; Smolander, A.; Simon, J. Tannins can slow-down but also speed-up soil enzymatic activity in boreal forest. Soil Biol. Biochem. 2017, 107, 60-67. [CrossRef]

13. Quiquampoix, H.; Burns, R.G. Interactions between Proteins and Soil Mineral Surfaces: Environmental and Health Consequences. Elements 2007, 3, 401. [CrossRef]

14. Sanjay, G.; Sugunan, S. Acid activated montmorillonite: An efficient immobilization support for improving reusability, storage stability and operational stability of enzymes. J. Porous Mater. 2008, 15, 359-367. [CrossRef]

15. Servagent-Noinville, S.; Revault, M.; Quiquampoix, H.; Baron, M.H. Conformational Changes of Bovine Serum Albumin Induced by Adsorption on Different Clay Surfaces: FTIR Analysis. J. Colloid Interface Sci. 2000, 221, 273-283. [CrossRef] [PubMed]

16. Zimmerman, A.R.; Ahn, M.-Y. Organo-Mineral-Enzyme Interaction and Soil Enzyme Activity. In Soil Enzymology; Shukla, G., Varma, A., Eds.; Springer Berlin Heidelberg: Berlin/Heidelberg, Germany, 2011; pp. 271-292. [CrossRef]

17. An, N.; Zhou, C.H.; Zhuang, X.Y.; Tong, D.S.; Yu, W.H. Immobilization of enzymes on clay minerals for biocatalysts and biosensors. Appl. Clay Sci. 2015, 114, 283-296. [CrossRef]

18. Tietjen, T.; Wetzel, R.G. Extracellular enzyme-clay mineral complexes: Enzyme adsorption, alteration of enzyme activity, and protection from photodegradation. Aquat. Ecol. 2003, 37, 331-339. [CrossRef]

19. Gianfreda, L.; Rao, M.A.; Violante, A. Adsorption, activity and kinetic properties of urease on montmorillonite, aluminium hydroxide and $\mathrm{AL}(\mathrm{OH}) \mathrm{x}-\mathrm{montmorillonite} \mathrm{complexes.} \mathrm{Soil} \mathrm{Biol.} \mathrm{Biochem.} \mathrm{1992,} \mathrm{24,} \mathrm{51-58.}$ [CrossRef]

20. Rao, M.A.; Violante, A.; Gianfreda, L. Interaction of acid phosphatase with clays, organic molecules and organo-mineral complexes: Kinetics and stability. Soil Biol. Biochem. 2000, 32, 1007-1014. [CrossRef] 
21. Nottingham, A.T.; Baath, E.; Reischke, S.; Salinas, N.; Meir, P. Adaptation of soil microbial growth to temperature: Using a tropical elevation gradient to predict future changes. Glob. Chang. Biol. 2019, 25, 827-838. [CrossRef]

22. Belotte, D.; Curien, J.B.; Maclean, R.C.; Bell, G. An experimental test of local adaptation in soil bacteria. Evolution 2003, 57, 27-36. [CrossRef] [PubMed]

23. Lammirato, C.; Miltner, A.; Wick, L.Y.; Kästner, M. Hydrolysis of cellobiose by $\beta$-glucosidase in the presence of soil minerals-Interactions at solid-liquid interfaces and effects on enzyme activity levels. Soil Biol. Biochem. 2010, 42, 2203-2210. [CrossRef]

24. Leprince, F.; Quiquampoix, H. Extracellular enzyme activity in soil: Effect of $\mathrm{pH}$ and ionic strength on the interaction with montmorillonite of two acid phosphatases secreted by the ectomycorrhizal fungus Hebeloma cylindrosporum. Activité enzymatique extracellulaire dans Ie sol: Effet du pH et de la force ionique sur l'interaction avec la montmorillonite de deux phosphates acides sécrdteés par le champignon ectomycorhizien Hebeloma cylindrosporum. Eur. J. Soil Sci. 1996, 47, 511-522. [CrossRef]

25. Safari Sinegani, A.A.; Emtiazi, G.; Shariatmadari, H. Sorption and immobilization of cellulase on silicate clay minerals. J. Colloid Interface Sci. 2005, 290, 39-44. [CrossRef] [PubMed]

26. Giaveno, C.; Celi, L.; Richardson, A.E.; Simpson, R.J.; Barberis, E. Interaction of phytases with minerals and availability of substrate affect the hydrolysis of inositol phosphates. Soil Biol. Biochem. 2010, 42, 491-498. [CrossRef]

27. Luckert, J.; Thieke, H.U. Der Mineralbestand brandenburgischer Grundmoränen als lithostratigraphischer Indikator-erste Ergebnisse der Röntgenphasenanalyse der Tillmatrix $<63 \mu \mathrm{m}$. Brandenburgische Geowiss. Beitr. 2000, 7, 101-113.

28. Sommer, M.; Augustin, J.; Kleber, M. Feedbacks of soil erosion on SOC patterns and carbon dynamics in agricultural landscapes-The CarboZALF experiment. Soil Tillage Res. 2016, 156, 182-184. [CrossRef]

29. Kirkels, F.M.S.A. The Fate of Eroded Soil Organic Carbon-Linking Terrestrial and Aquatic Carbon Cycling; University of Amsterdam: Amsterdam, The Nertherlands, 2014.

30. Kaiser, M.; Ellerbrock, R.H.; Sommer, M. Separation of Coarse Organic Particles from Bulk Surface Soil Samples by Electrostatic Attraction. Soil Sci. Soc. Am. J. 2009, 73, 2118-2130. [CrossRef]

31. Gianfreda, L.; Rao, M.A. Stabilizing Enzymes as Synthetic Complexes. In Methods of Soil Enzymology; Dick, R.P., Ed.; Soil Science Society of America: Madison, WI, USA, 2011; pp. 319-369. [CrossRef]

32. Deng, S.; Kang, H.; Freeman, C. Microplate Fluorimetric Assay of Soil Enzymes. In Methods of Soil Enzymology; Dick, R.P., Ed.; Soil Science Society of America: Madison, WI, USA, 2011; pp. 311-318. [CrossRef]

33. Geisseler, D.; Horwath, W.R. Relationship between carbon and nitrogen availability and extracellular enzyme activities in soil. Pedobiologia 2009, 53, 87-98. [CrossRef]

34. Marx, M.C.; Kandeler, E.; Wood, M.; Wermbter, N.; Jarvis, S.C. Exploring the enzymatic landscape: Distribution and kinetics of hydrolytic enzymes in soil particle-size fractions. Soil Biol. Biochem. 2005, 37, 35-48. [CrossRef]

35. Dick, W.A. Kinetics of Soil Enzyme Reactions. In Methods of Soil Enzymology; Dick, R.P., Ed.; Soil Science Society of America: Madison, WI, USA, 2011; pp. 57-69. [CrossRef]

36. Nannipieri, P.; Giagnoni, L.; Renella, G.; Puglisi, E.; Ceccanti, B.; Masciandaro, G.; Fornasier, F.; Moscatelli, M.C.; Marinari, S. Soil enzymology: Classical and molecular approaches. Biol. Fertil Soils 2012, 48, 743-762. [CrossRef]

37. German, D.P.; Weintraub, M.N.; Grandy, A.S.; Lauber, C.L.; Rinkes, Z.L.; Allison, S.D. Optimization of hydrolytic and oxidative enzyme methods for ecosystem studies. Soil Biol. Biochem. 2011, 43, 1387-1397. [CrossRef]

38. Baldrian, P.; Šnajdr, J.; Merhautová, V.; Dobiášová, P.; Cajthaml, T.; Valášková, V. Responses of the extracellular enzyme activities in hardwood forest to soil temperature and seasonality and the potential effects of climate change. Soil Biol. Biochem. 2013, 56, 60-68. [CrossRef]

39. R Core Team. R: A Language and Environment for Statistical Computing; R Foundation for Statistical Computing: Vienna, Austria, 2018; Available online: http://www.R-project.org/ (accessed on 12 May 2018).

40. Pflug, W. Effect of clay minerals on the activity of polysaccharide cleaving soil enzymes. Zeitschrift für Pflanzenernährung und Bodenkunde 1982, 145, 493-502. [CrossRef]

41. Quiquampoix, H. A stepwise approach to the understanding of extracellular enzyme activity in soil II. Competitive effects on the adsorption of a $\beta$-d-glucosidase in mixed mineral or organo-mineral systems. Biochimie 1987, 69, 765-771. [CrossRef] 
42. Uddin, F. Clays, Nanoclays, and Montmorillonite Minerals. Metall. Mater. Trans. A 2008, 39, $2804-2814$. [CrossRef]

43. Allison, S.D. Soil minerals and humic acids alter enzyme stability: Implications for ecosystem processes. Biogeochemistry 2006, 81, 361-373. [CrossRef]

44. Secundo, F. Conformational changes of enzymes upon immobilisation. Chem. Soc. Rev. 2013, 42, 6250-6261. [CrossRef]

45. Quiquampoix, H.; Servagent-Noinville, S.; Baron, M.-H. Enzyme Adsorption on Soil Mineral Surfaces and Consequences for the Catalytic Activity. In Enzymes in the Environment; Marcel Dekker: New York, NY, USA, 2002; pp. 285-306.

46. Horton, R.; Moran, L.; Scrimgeour, G.; Perry, M.; Rawn, D. Principles of Biochemistry, 4th ed.; Prentice Hall: Upper Saddle River, NJ, USA, 2005; Chapter 5; pp. 149-151, citeulike-article-id:7374718.

47. Wei, H.; Guenet, B.; Vicca, S.; Nunan, N.; Asard, H.; AbdElgawad, H.; Shen, W.; Janssens, I.A. High clay content accelerates the decomposition of fresh organic matter in artificial soils. Soil Biol. Biochem. 2014, 77, 100-108. [CrossRef]

48. Wardle, D.A. A comparative assessment of factors which influence microbial biomass carbon and nitrogen levels in soil. Biol. Rev. 1992, 67, 321-358. [CrossRef]

49. Haider, K.; Filip, Z.; Martin, J.P. Einfluß von Montmorillonit auf die Bildung von Biomasse und Stoffwechselzwischenprodukten durch einige Mikroorganismen. Arch. für. Mikrobiol. 1970, 73, 201-215. [CrossRef]

50. Stotzky, G.; Rem, L.T. Influence of clay minerals on microorganisms: I. Montmorillonite and Kaolinite on bateria. Can. J. Microbiol. 1966, 12, 547-563. [CrossRef] [PubMed]

51. Allison, S.D.; Weintraub, M.N.; Gartner, T.B.; Waldrop, M.P. Evolutionary-economic principles as regulators of soil enzyme production and ecosystem function. In Soil Enzymology; Springer: Berlin, Germany, 2011; pp. 229-243.

52. Schimel, J.P.; Weintraub, M.N. The implications of exoenzyme activity on microbial carbon and nitrogen limitation in soil: A theoretical model. Soil Biol. Biochem. 2003, 35, 549-563. [CrossRef]

53. Malik, A.A.; Puissant, J.; Goodall, T.; Allison, S.D.; Griffiths, R.I. Soil microbial communities with greater investment in resource acquisition have lower growth yield. Soil Biol. Biochem. 2019, 132, 36-39. [CrossRef]

54. Romero, M.D.; Aguado, J.; González, L.; Ladero, M. Cellulase production by Neurospora crassa on wheat straw. Enzym. Microb. Technol. 1999, 25, 244-250. [CrossRef]

55. Kedi, B.; Sei, J.; Quiquampoix, H.; Staunton, S. Persistence of catalytic activity of fungal phosphatases incubated in tropical soils. Soil Biol Biochem. 2013, 56, 69-74. [CrossRef]

56. Kedi, B.; Abadie, J.; Sei, J.; Quiquampoix, H.; Staunton, S. Diversity of adsorption affinity and catalytic activity of fungal phosphatases adsorbed on some tropical soils. Soil Biol. Biochem. 2013, 56, 13-20. [CrossRef]

57. Hoffman, M.; Decho, A.W. Extracellular enzymes within microbial biofilms and the role of the extracellular polymer matrix. In Microbial Extracellular Polymeric Substances; Springer: Berlin, Germany, 1999; pp. 217-230.

58. Liang, C.; Schimel, J.P.; Jastrow, J.D. The importance of anabolism in microbial control over soil carbon storage. Nat. Microbiol. 2017, 2, 17105. [CrossRef]

(C) 2019 by the authors. Licensee MDPI, Basel, Switzerland. This article is an open access article distributed under the terms and conditions of the Creative Commons Attribution (CC BY) license (http://creativecommons.org/licenses/by/4.0/). 